\title{
НЕФТЕГАЗОНОСНОСТЬ КОРЫ ВЫВЕТРИВАНИЯ И ПАЛЕОЗОЯ КОЛТОГОРСКОГО МЕЗОПРОГИБА (СЕВЕРО-ЗАПАД ТОМСКОЙ ОБЛАСТИ)
}

\author{
Лобова Галина Анатольевна', \\ lobovaga@tpu.ru
}

Лунёва Татьяна Евгеньевна', tatyana.luneva93@gmail.com

\author{
Исаева Ольга Степановна², \\ isaeva_sah@mail.ru \\ ' Национальный исследовательский Томский политехнический университет, \\ Россия, 634050, г. Томск, пр. Ленина, 30. \\ 1 Томский филиал ФБУ «Территориальный фонд геологической информации по Сибирскому федеральному округу», \\ Россия, 634034, г. Томск, ул. Мокрушина, д. 9, стр. 16.
}

\begin{abstract}
Актуальность исследования определена необходимостью восполнения сырьевой базы за счет трудноизвлекаемых запасов в доюрском нефтегазоносном комплексе, в связи с истощением «классических» нефтегазоносных горизонтов Западной Сибири. Цель: определение перспективных участков для постановки поисковых работ в доюрском нефтегазоносном комплексе в Колтогорском мезопрогибе - на землях развитой промысловой инфраструктуры Томской области.

объектом исследования являются доюрские резервуары, включающие пермо-триасовую кору выветривания и палеозойские породы фундамента, в границах распространения нефтематеринской тогурской свиты. Резервуар коры выветривания - это коллекторы, образованные по карбонатным, терригенно-карбонатным, глинисто-кремнистым и магматическим породам кислого состава, резервуар внутреннего палеозоя - вторичные коллекторы карбонатных отложений и интрузивных пород кислого состава. Методы. Исследование проводится в рамках концепции преимущественно вертикальной миграции углеводородов. Ранее выполненное восстановление термической истории тогурской свиты, кумулятивно учитывающее температуры локализованных палеоочагов генерации нефти, позволило закартировать распределение плотности генерации нефтей. Последующим интегральным анализом, с учетом фильтрационно-емкостных характеристик резервуаров и разрывной тектоники палеозоя, выполняется зональное нефтегеологическое районирование доюрского комплекса и ранжирование земель по степени перспективности. В результате исследования проведено зональное районирование территории с высоким потенциалом в отношении нефтегазоносности, раздельно для резервуаров коры выветривания и внутреннего палеозоя. Наиболее перспективной по коре выветривания является восточная часть Черемшанской мезоседловины, зона ее сочленения с северным бортом Колтогорского мезопрогиба и западным склоном Средневасюганского мегавала (порядка 3500 км²). Первоочередными на поиск залежей в резервуарах внутреннего палеозоя являются те же земли, что и для коры выветривания. Второй участок, с такой же степенью перспективности, объединяет Северо-Чкаловский врез и зону его сочленения с Мурасовским выступом и Трассовым куполовидным поднятием (порядка 5700 км²). Достоверность прогноза перспективных земель доюрского нефтегазоносного комплекса определяется сопоставлением с результатами испытаний глубоких скважин и составляет порядка 70 \%.
\end{abstract}

\section{Ключевые слова:}

Тогурская свита, термическая история и плотность генерации нефти, резервуары коры выветривания и внутреннего палеозоя, нефтегеологическое районирование, Колтогорский мезопрогиб.

\section{Введение}

В связи с истощением «классических» нефтегазоносных комплексов для территории Западной Сибири появился огромный интерес к глубокозалегающим стратиграфическим горизонтам, относящимся к категории трудноизвлекаемых [1]. Одним из таких объектов являются резервуары доюрского нефтегазоносного комплекса (НГК) [2]. Даже несмотря на то, что нет единого мнения среди геологов в отношении высокой перспективности доюрских отложений Западной Сибири, все же отмечается важность вклада доюрской нефти в сырьевую базу России [3]. Преимуществом с экономической точки зрения для Колтогорского мезопрогиба является его расположение на территории с уже развитой инфраструктурой нефтепромыслов (рис. 1, А). Но на данный момент стоит проблема, заключающаяся в трудности поиска и разведки залежей в доюр- ском комплексе из-за сложной дизъюнктивной тектоники, блочного строения и ограничения распространения резервуаров по латерали. Несмотря на достаточно длительный период освоения Западной Сибири, недропользователи редко ставят целью своих работ поиск и разведку таких залежей, поскольку пока идет добыча из меловых и верхнеюрских пластов. Поиски залежей в коре и фундаменте в основном проводятся попутно с вышележащими объектами, поэтому скважины закладываются исключительно исходя из положения ловушек в юрских и меловых отложениях в апикальной части поднятий, что часто ведет к отрицательным результатам для освоения доюрского комплекса.

В последнее десятилетие изучению сложных геологических объектов, в том числе и в доюрском фундаменте, посвящены многие работы. Появляются исследования по проблемам выделения перс- 
пективных территорий для поисков скоплений нефти и газа в глубокозалегающих доюрских комплексах Западной Сибири [2, 4], предлагаются стратегии их поисков [5].

Большой упор при изучении сложных объектов делается на бассейновое моделирование, которое позволяет восстанавливать историю прогрева осадочного чехла и процессы нефтегазогенерации. В данной работе используются результаты моделирования термической истории и реализации генерационного потенциала нефтематеринской тогурской свиты Колтогорского мезопрогиба и структур его обрамления (рис. 1, Б) [6].
Цель исследования - выполнить зональную оценку перспектив нефтегазоносности доюрских резервуаров Колтогорского мезопрогиба и структур обрамления и определить первоочередные участки поисков на доюрский нефтегазоносный комплекс.

\section{Краткая характеристика нефтегазоносности территории}

Территория исследования расположена в северо-западной части Томской области и в структурах осадочного чехла приурочена к Нюрольско-Колтогорскому желобу, оконтуренному положительны-

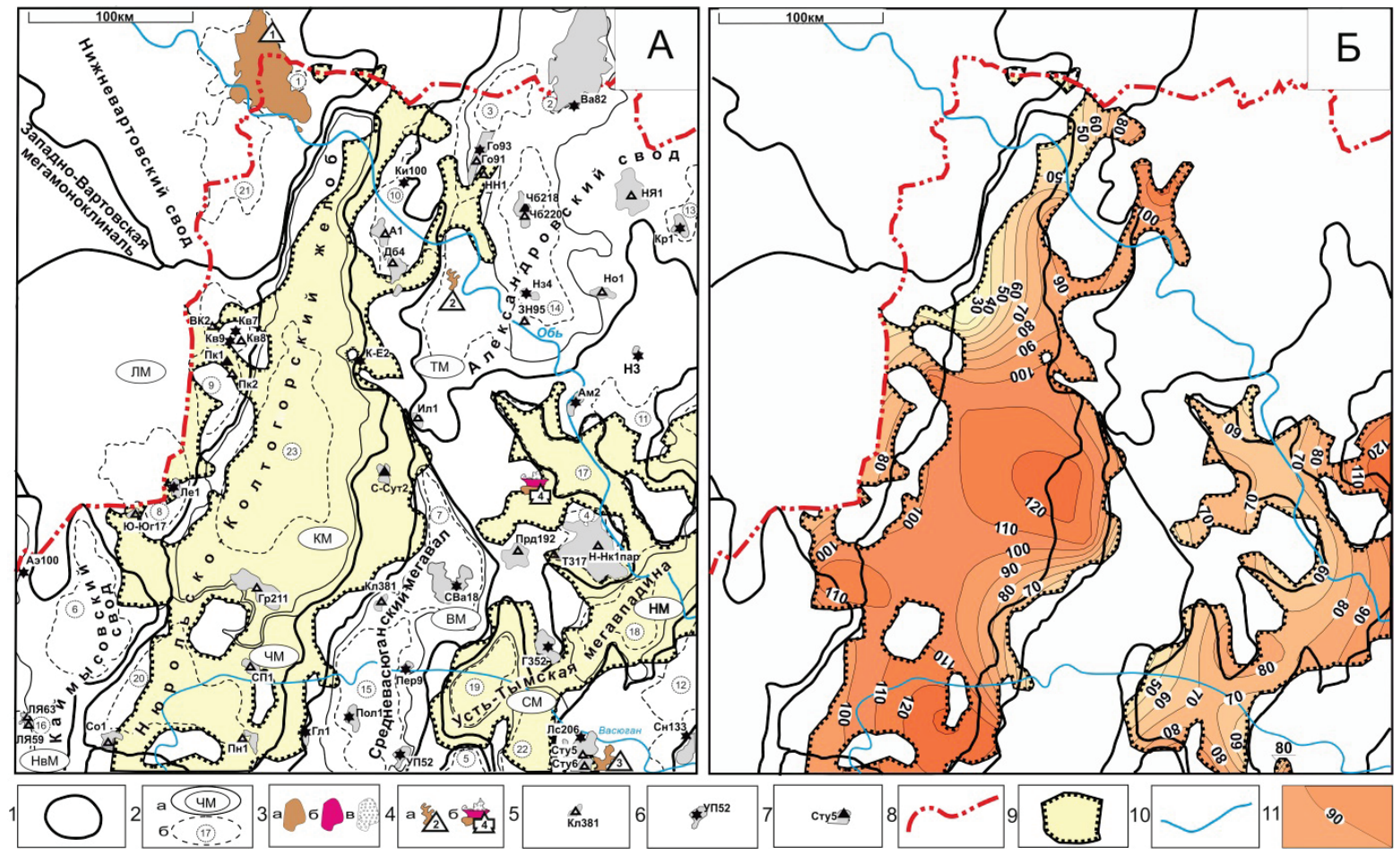

Pис.1. Колтогорский мезопрогиб и структуры обрамления. На тектонической основе [10] схема нефтегазоносности (А) и схематическая карта плотности генерации тогурской нефти [6] (Б). К схеме (A): тектонический элемент: 1 - I-го порядка; 2 - II-го порядка и его условный индекс (а): мезоседловины: ЛМ - Ледянская, ЧМ - Черемшанская; мезовалы: ТМ - Трайгородский, ВМ - Васюганский, НвМ - Нововасюганский; мезопрогибы: КМ - Колтогорский, НМ - Неготский, СМ - Сампатский; III-го порядка и его номер (б): куполовидные поднятия: 1 - Советско-Соснинское, 2 - Вахское, 3 - Охтеурское, 4 - Трассовое, 5 - Мыльджинское, 6 - Катыльгинское, 7 - Северо-Васюганское, 8 - Ледовое, 9 - Кедровско-Матюшкинское; выступы: 10 - Западно-Александровский, 11 - Мурасовский, 12 - Тростниковый; валь: 13 - Окуневский, 14 - Криволуикий, 15 - Новотевризский, 16 - Лонтыньяхский; врезы: 17 - Северо-Чкаловский; впадины: 18 - Южно-Неготскал, 19 - Северо-Мыльджинская, 20 - Южно-Колтогорская, 21 - Малореченская; прогибы: 22 - Центральный; 23 - Ильякский; 3 - месторождение: а) нефтяное, б) конденсатное, в) газовое; 4 - месторождение с залежами: а) в НГГЗК: 1 - Советское; 2 - Конторовичское, 3 - Ясное, б) в коре выветривания и палеозое: 4 - Чкаловское; скважина, ее условный индекс и результаты испытания (5- сухо, 6 - приток воды, 7 - приток УВ при испытании), 8 - административная граница Томской области; 9 - зона распространения тогурской свиты; 10 - речная сеть. К схематической карте (Б): 11 - изолинии плотности генерации тогурских нефтей, усл.ед.

Fig. 1. Koltogor mezodepression and its framing structures. On the tectonic foundation of [10] scheme of oil and gas content (A) and distribution of generated Togur oil density values [6] ( $B$ ). To figure (A): the tectonic element: 1 - I; 2 - II and its index (a): mezosaddle: JM the Ledyansk, YM - Cheremshanka; mezoswell: TM - the Traygorod, BM - the Vasyugan, HвM - the New-Vasyugan; mezodepression: KM - the Koltogor, HM - the Negot, CM - the Sampat; III and its index (b): arched dome: 1 - the Soviet-Sosninsk, 2 - the Vakh, 3 the Okhteur, 4 - the Trass, 5 - the Myldzhin, 6 - the Katylgin, 7 - the North-Vasyugan, 8 - the Ledov, 9 - the Kedrov-Matyushkin; anticlinal nose: 10 - the West-Aleksander, 11 - the Murasov, 12 - Trostnik; arch: 13 - the Okunevsky, 14 - the Krivolutsk, 15 - the Novotevrizsky, 16 - the Lontiniah; shut-in: 17 - the North-Chkalovsky; depressions: 18 - the South-Negot, 19 - the North-Myldzhin, 20 - the South-Koltogor, 21 - the Malorechen; downwarp: 22 - the Central; 23 - the Ilyaksky; 3 - the field: a) oil, б) condensate, в) gas; 4 - field with pools: a) in the contact area oil and gas bearing zone: 1 - Soviet, 2 - Kontorovich, 3 -Yasny; 0 ) in Weathering Crust and Paleozoic: 4 - Chkalovsky; well, its index and well test results (5-dry well, 6 - water influx, 7-hydrocarbon influx during testing); 8 -administrative boundary of Tomsk region; 9 - boundary of the Togur suite; 10 - river system. To figure (B): 11 - contour of generated Togur oil density values, conv. units 
ми структурами (рис. 1, А). По нефтегеологическому районированию [7], эти земли находятся в зоне сочленения трех нефтегазоносных областей Западно-Сибирской нефтегазоносной мегапровинции: Среднеобской, Каймысовской и Васюганской. Здесь, наряду с меловым (неокомским), верхнеюрским (келловей-волжским), среднеюрским (байосбатским), нижнеюрским (геттанг-раннетоарским, позднетоар-ааленским) нефтегазоносными комплексами, выделяется и доюрский НГК (горизонт зоны контакта - НГГЗК и собственно внутренний палеозой) [8].

Общепринято, что для среднеюрского, верх неюрского и мелового НГК нефтематеринской является баженовская свита [9].

Основной нефтегенерирующей толщей для залежей нижнеюрского и доюрского НГК по мнению многих ученых признается тогурская свита. Однако ряд исследователей $[11,12]$ предлагают рассматривать так называемые девонские «доманики» в качестве нефтегенерирующих. Такое мнение возникло еще с самого начала открытия палеозойской нефти в Западной Сибири на Колпашевской площади в скважине 2-Р [13]. Также предполагается наличие смешанных источников одновременно: как палеозойских, так и юрских [3]. Геохимическими исследованиями определена возможность вертикальной миграции УВ из раннетоарской нефтегенерирующей толщи в доюрские отложения $[14,15]$, величина которой может составить порядка $150 \ldots 250$ м [16].

На территории исследования тогурская свита залегает в депрессионных зонах Нюрольско-Колтогорского желоба, западной части Усть-Тымской мегавпадины, формируясь в бортах, изрезанных каньонообразными прогибами, выклиниваясь на эрозионно-тектонических выступах доюрского основания. Мощность тогурских отложений колеблется от 0 до $40 \mathrm{~m}$, увеличиваясь в наиболее погруженных частях, таких как Ильякский прогиб, Северо-Мыльджинская впадина, более чем на $160 \mathrm{~m}$.

Эрозионно-тектонические выступы доюрского основания являются местом локализации залежей углеводородов, связанных со сложнопостроенными литологически-, тектонически- и стратиграфически экранированными ловушками. Формированию последних двух типов ловушек способствует наличие достаточно развитой разломной тектоники на территории (рис. 2, А).

Кроме того, гипергенно-гидротермальные процессы, происходящие в рассматриваемых отложениях, приводят к образованию отдельных типов ловушек в резервуарах коры выветривания.

Нижнеюрские флюидоупоры рассматриваются в качестве покрышки для залежей в резервуарах коры выветривания. При выклинивании нижнеюрских отложений роль покрышки могут выполнять среднеюрские локальные глинистые пачки. Для залежей во внутреннем палеозое покрышками могут служить непроницаемые разности вы- ше залегающей коры выветривания или, при отсутствии ее, те же флюидоупоры, что и для НГГЗК. Часто залежи доюрского НГК оказываются гидродинамически связанными и образующими общий этаж нефтеносности.

В пределах территории исследования в доюрском НГК к нефтегазоноснолу горизонту зонь контакта (НГГЗК, пласт М) приурочены четыре месторождения нефти (рис. 1, А). На этом же стратиграфическом уровне получены прямые признаки при бурении скважин Приколтогорская 1 (Пк1, рис. 1, А), Ступенчатая 5 (Сту5), Чебачья 218 (Чб218). Открыто одно месторождение, содержащее залежь в объединенном резервуаре НГГЗК и внутреннего палеозоя (пласт $\mathrm{M}_{1}$ ). В палеозойских отложениях признаки нефтегазоносности зафиксированы в скважине Северо-Сутыгинская 2 (С-Сут2), где при испытании получен приток разгазированной воды.

\section{О методике проведения исследований}

Мы придерживаемся мнения о вертикальной миграции как преимущественной, поэтому прогнозирование проводится в контуре распространения тогурской нефтематеринской свиты. На предыдущем этапе наших исследований [6], с использованием технологии палеотемпературного моделирования [17-19], была выявлена пространственновременная локализация очагов генерации углеводородов, рассчитана и закартирована плотность генерации тогурских нефтей, в условных единицах. С учетом этого параметра (рис. 1, Б), а также с учетом мощности и качества коллекторов доюрских резервуаров, разрывной тектоники, строятся схемы распределения плотности аккумулированных тогурских нефтей и проводится ранжирование территории исследования по степени перспективности отдельно для НГГЗК и внутреннего палеозоя.

\section{Резервуар коры выветривания}

На территории исследования представлен достаточно большой спектр литологических разновидностей доюрских отложений (рис. 2, А), выходящих на поверхность фундамента, по которым и образуются разнообразные профили кор выветривания. Существенную часть территории исследования занимают пермо-триасовые трапповые образования вулканогенно-осадочной туринской серии. Породы вулканогенного типа вскрыты на Саймовской 1 (Сa1, рис. 2, А), Куль-Еганской 6 (КЕ6), Куль-Еганской 2 (К-Е2), Грушевой 211 (Гр211) и представлены порфиритовыми эффузивными диабазами и долеритами. Эти отложения практически не образуют кор выветривания, а если подвергаются выветриванию, то пустотностей в них практически нет. В случае же полнопрофильных преобразований по этим породам образуются глины с преобладанием монмориллонита. Такие толщи обладают хорошими флюидоупорными свойствами. По карбонатно-вулканогенным породам, вследствие гидротермальных процессов, обра- 
зуются такие породы, как метаморфизованная древесная брекчия, вскрытая в скважине ЮжноПионерская 263 (ЮП263, рис. 2, А), которая не отличается повышенными фильтрационно-емкостными свойствами (ФЕС). Гидротермально измененный дацит в скважине Западно-Тымская 1 (3T1) также оказался слабопроницаемым. Процессы доломитизации, окремнения и пиритизации по терригенным породам приводят к закупориванию пористого пространства глинистыми разностями и потере фильтрационных свойств.

По мнению исследователей [20, 21] по карбонатным, терригенно-карбонатным, глинисто-кремнистым и магматическим породам кислого состава образуются коллекторы, характеризующиеся хорошими ФЕС. Такие разновидности пород слагают Северо-Чкаловский врез, Северо-Мыльджинскую впадину и восточную часть Черемшанской мезо- седловины. В подтверждение этому факту из интенсивно выветрелых микрогранитов в скважине Ступенчатая 5 (Сту5) получен приток нефти с водой. Измененные липариты, вскрытые в скважинах на Ясной и Конторовичской площадях, также оказались нефтенасыщенными. С выветрелыми известняками, слагающими пласт М, связаны залежи на Чкаловском и Советском месторождениях.

Анализ построенной карты изопахит коры выветривания по данным 126 скважин показал, что мощность отложений на территории исследования достаточно изменчива (рис. 2, Б). Отложения выклиниваются не только на локальных участках, но и на достаточно большой территории, ориентированной в северо-восточном направлении в центральной части Колтогорского мезапрогиба, УстьТымской мегавпадины, а также в зоне их сочленения. Наибольшие значения толщин достигаются в

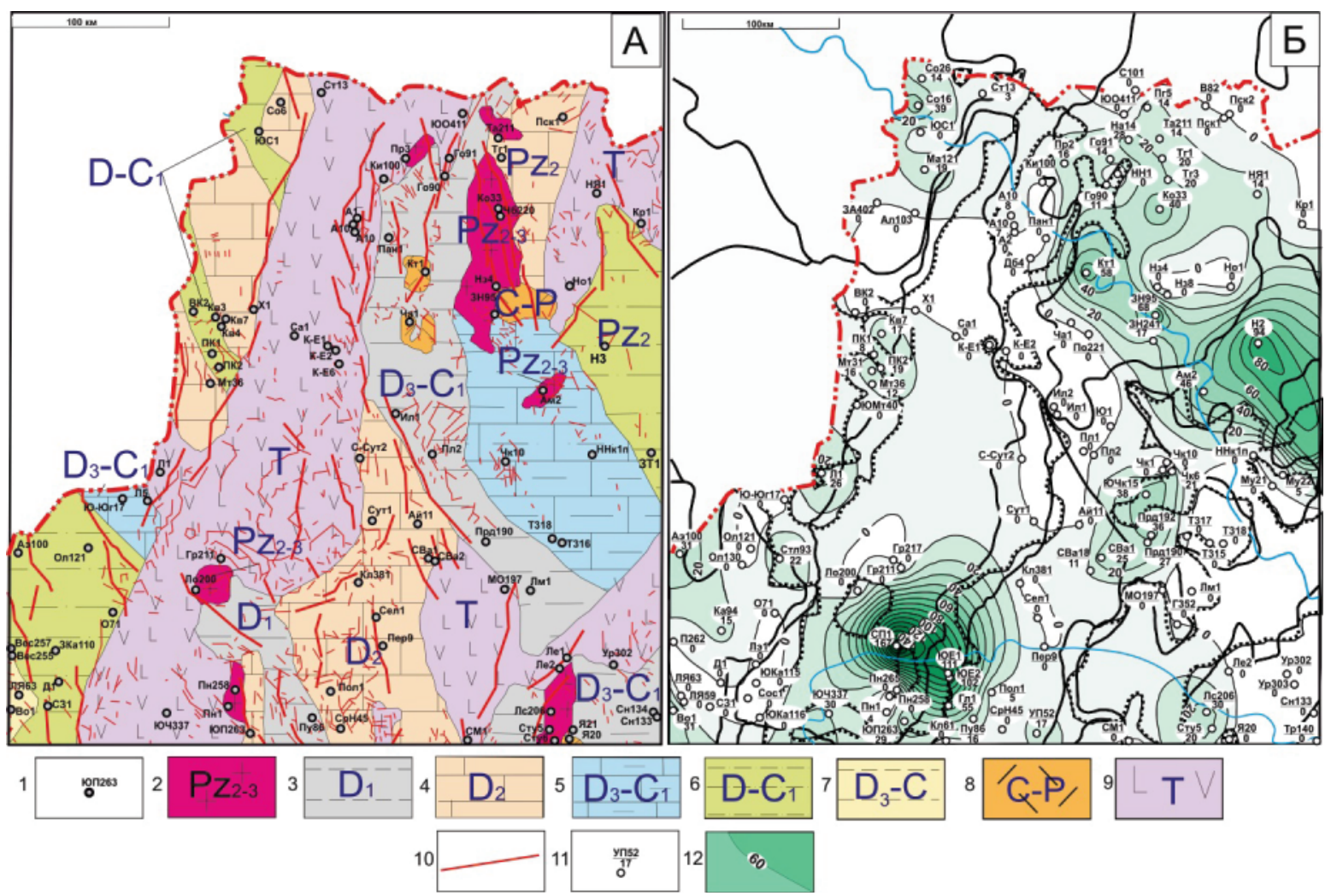

Рис. 2. Колтогорский мезопрогиб и структуры обрамления. Схема петротипов пород фундамента и дизбюнктивных нарушений, с использованием [10] (А) и схематическая карта изопахит коры выветривания (Б). К схеме (A): 1 - скважина, в которой анализировалась литологическая характеристика доюрских отложений; фация комплекса пород фундамента с датировкой возраста: 2 - средне-позднепалеозойская гранитная, 3 - раннедевонская глинисто-кремнистая сланщевая, 4 - среднедевонская карбонатная, 5 - позднедевонско-реннекаменноугольная терригенно-карбонатная; 6 - девон-раннекаменноугольная терригенная; 7 - позднедевон-каменноугольная глинисто-сланиевал, 8 - карбон-пермская липаритовая, 9 - триасовая андезито-базальтовая; 10 - дизбюнктивы. К схематической карте (Б): 11 - скважина, данные которой использованы для построения карты толщин коры выветривания, в числителе указан условный индекс скважины, в знаменателе - мощность коры, м; 12 - изопахиты, м. Остальные те же, что на рис. 1

Fig. 2. Koltogor mezodepression and its framing structures. Scheme of rocks petrotype of basement and faults using [10] (A) and schematic maps of isopachytes of weathering crust (B). To figure $(A)$ : 1 - well, which analyzed the lithological characteristics of Pre-Jurassic deposits; facies of a complex of basement rocks with age dating: 2 - granite Middle-Late Paleozoic; 3 - clay-siliceous shale Early Devonian; 4 - carbonate Middle Devonian; 5 - terrigenous carbonate Late Devonian-Early Carboniferous; 6 - terrigenous Devonian-Early Carboniferous; 7 - clay-slate Late Devon-Carboniferous; 8 - liparite Carboniferous-Permian, 9 - andesite-basaltic Triassic; 10 - faults. To figure (B): 11 - well, used for mapping isopachytes: conditional index is in numerator, thickness of weathering crust reservoirs is in denominator; 12 - isopachytes of the weathering crust, $m$. The rest symbols are the same as in Fig. 1 
южной части Черемшанской мезоседловины (167 м в скважине Северо-Пионерская 1). Важную роль здесь могут играть тектонические процессы, которые ведут к формированию трещиноватых зон, что способствует образованию кор выветривания.

\section{Распределение плотности аккумуляции тогурской нефти и районирование резервуара коры выветривания}

Значения распределения плотности первичной аккумуляции тогурской нефти (усл. ед.) для коры выветривания (рис. 3, А) рассчитаны перемножением матрицы значений мощности коры (рис. 2, Б) и матрицы значений плотности генерации тогурской нефти (рис. 1, Б).

Районирование перспектив территории основывается на комплексном учете следующих параметров: плотность первичной аккумуляции тогурской нефти (рис. $3, \mathrm{~A}$ ); распространение петротипов пород фундамента (рис. 2, A), по которым могут образовываться коллекторы в коре выветривания с хорошими ФЕС (рис. $3, \mathrm{~A})$; наличие разломной тектоники (рис. $2, \mathrm{~A})$.

В результате учета всех параметров территория разделена на две зоны по приоритету. Наиболее перспективно первоначально проводить поисковые геолого-геофизические работы на землях зоны 1, приуроченных к восточной части Черемшанской мезоседловины и ее сочленению с северным бортом Колтогорского мезопрогиба и с западным склоном Средневасюганского мегавала. При совместном испытании в скважине Северо-Пионерской 1 (СП1, рис. 3, Б) резервуаров коры выветривания и палеозоя в интервале 3201-3234 м притока не получено, что, возможно, связано с неверным выбором интервала испытания ввиду недостаточной геолого-геофизической изученности разреза. Отсутствие притоков в скважинах Пионерская 1, Южно-Пионерских 261, 263 (рис. 3, Б, индекс скважин Пн1, ЮП261, ЮП263), расположенных за пределами перспективной зоны, подтверждают границы зоны.

Следующей по приоритету идет зона 2 , которая в свою очередь представлена двенадцатью участками. Оценка их степени перспективности определяется исходя из двух критериев: по наличию дизъюнктивных нарушений, с учетом площади участков.

Высокая перспективность участка 2.1, приуроченного к Северо-Чкаловскому врезу и зоне его сочленения с Мурасовским выступом, подтвер-

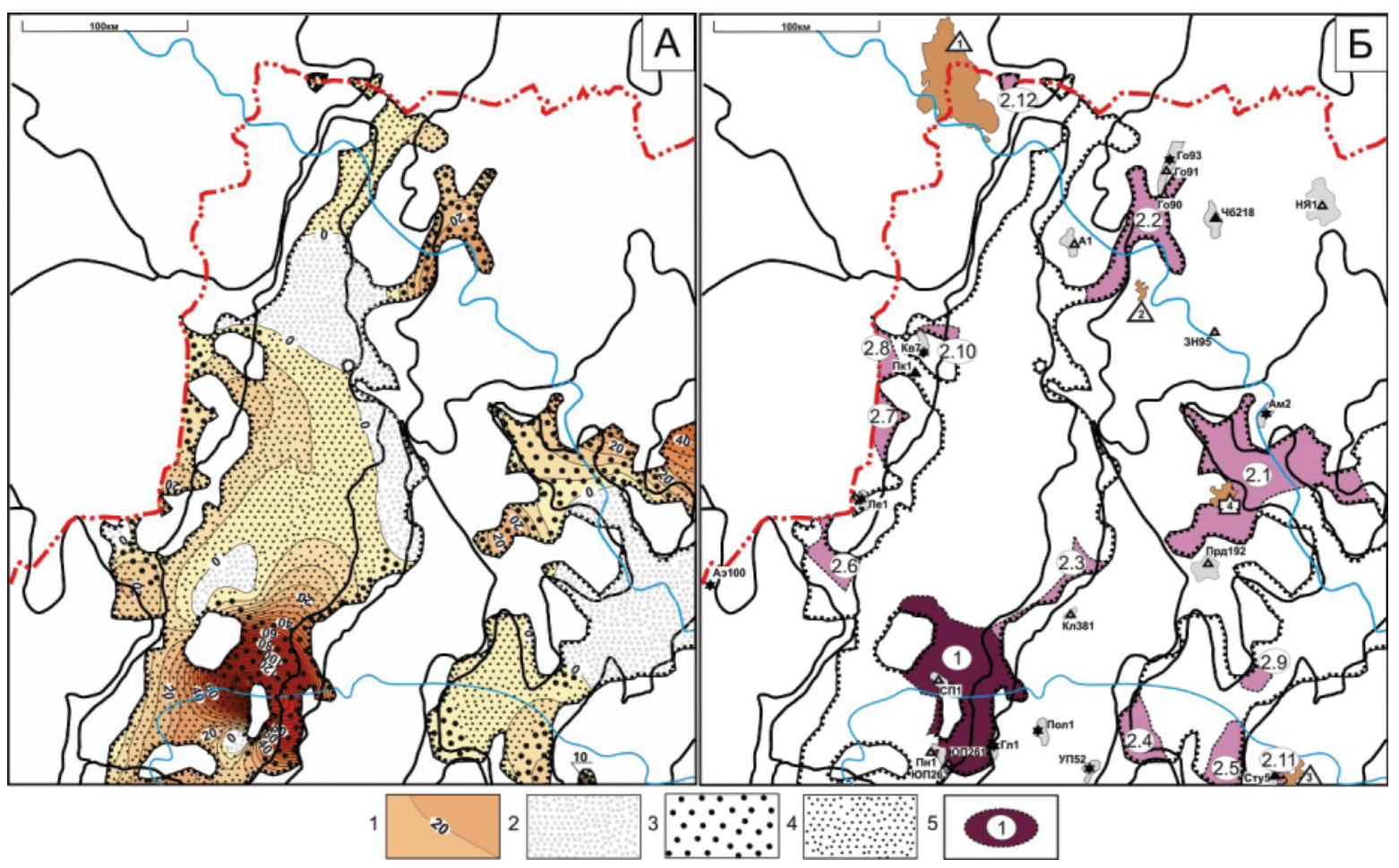

Рис. 3. Колтогорский мезопрогиб и структуры обрамления. Кора выветривания. Распределение плотности первичной аккумуляции тогурской нефти и качества коллекторов (A), ранжирование зон и участков по степени перспективности (Б). $K$ схеме $(A)$ : 1 - изолинии плотности аккумуляции нефти, усл. ед.; 2 - отсутствие коры; зона коллекторов: 3 - с хорошими ФЕС, 4 - с пониженными ФЕС. К схеме (Б): 5 - перспективная зона (участок), номер ранжирования (интенсивность закраски пропорииональна степени перспективности). Остальные те же, что на рис. 1

Fig. 3. Koltogor mezodepression and its framing structures. The Weathering Crust. The density resources of the primary-accumulated Togur oils and the quality reservoirs $(A)$, ranking of priority areas for exploration $(B)$. To figure $(A)$ : 1 - isoline of resource density, conv. unit; 2 - lack of weathering crust; zone of resources: 3 - with good FCP; 4 - with reduced FCP. To figure (B): 5 - prospective zone (section), ranking number (intensity of area coloring is proportional to the degree). The rest symbols are the same as in Fig. 1 
ждается наличием нефтяной залежи в НГГЗК на Чкаловском месторождении.

Участок 2.2 расположен на западном склоне Александровского свода, его граница хорошо контролируется отсутствием притока на Горстовой площади в скважине 90 (Го 90 , рис. 3 , Б), расположенной за пределами участка и вскрывшей отложения литокластического туфа андезитового порфирита и долерита.

Участок 2.3 приурочен к землям сочленения Колтогорского мезопрогиба и Средневасюганского мегавала. Далее следуют участки 2.4 u 2.5, расположенные на территории западного борта ЮжноНеготской впадины и северной части Центрального прогиба, соответственно. Участки 2.6 u 2.7 приурочены к южному склону Ледового куполовидного поднятия и западному склону КедровоМатюшкинского куполовидного поднятия, соответственно. Перспективность этих участков не подтверждена из-за отсутствия данных о насыщении пласта М.

Участок 2.8 приурочен к северо-восточному склону Кедрово-Матюшкинского куполовидного поднятия. Перспективность данного участка иллюстрируется полученным притоком газа и пленки нефти в Приколтогорской скважине 1 (Пк1, рис. 3, Б), расположенной в непосредственной близости от границы участка.

Далее выделены локальные участки $2.9 u$ 2.10 в зоне сочленения Южно-Неготского прогиба и Северо-Мыльджинской впадины и в зоне сочленения Кедрово-Матюшкинского куполовидного поднятия и Колтогорского мезопрогиба, соответственно, на которых нет подтверждения перспективности. Участок 2.11 в юго-восточной части территории исследования подтверждает свой высокий потенциал наличием нефтяной залежи на Ясном месторождении, а также притоком нефти в скважине Ступенчатая 5 (Сту5), вскрывшей кору выветривания, образовавшуюся по граниту. Локальный участок 2.12 расположен в районе восточного склона Советско-Соснинского куполовидного поднятия и не имеет сведений о прямых признаках нефтенасыщения.

Наличие открытых нефтяных залежей Конторовичского месторождения и непромышленного притока на Чебачьей структуре в скважине 218 (Чб218), расположенных за пределами распространения нефтематеринской свиты, вероятно, объясняется непосредственным примыканием тогурской толщи к эрозионным выступам фундамента, что дает возможность латеральной миграции УВ в рассматриваемый резервуар. Что касается залежи на Советском месторождении, то, возможно, нефтепроизводящей здесь является радомская пачка или глинистые прослои среднеюрской тюменской свиты. Также вероятен вариант, где в качестве нефтегенерирующей толщи можно предположить и внутрипалеозойский (доманиковый) источник. Вопрос генезиса доюрской залежи Советского месторождения нуждается в дополнительной проработке.
В остальных скважинах, находящихся вне развития тогурской свиты, получены притоки пластовой воды без признаков нефтенасыщения или приток отсутствует, что согласуется с выполненным прогнозом (рис. 3, Б).

Согласованность выделенных перспективных зон резервуара коры выветривания и признаков нефтенасыщения, по результатам испытаний глубоких скважин, составляет порядка $70 \%$.

В результате выделения перспективных земель наиболее приоритетной в отношении нефтегазоносности резервуара коры выветривания является зона 1, которая охватывает восточные земли Черемшанской мезоседловины, участки ее сочленения с северным бортом Колтогорского мезопрогиба и с западным склоном Средневасюганского мегавала.

\section{Палеозойский резервуар}

Породы, слагающие палеозойские отложения на территории исследования, по генезису можно разделить на три группы: осадочные, магматические и метаморфические. Каждая из групп характеризуется различными литологическими разновидностями (рис. 2, А). Резервуары в доюрском НГК внутреннего палеозоя могут формироваться за счет вторичных минералогических процессов и образования трещиноватости [22]. Данные процессы в различной степени влияют на развитие вторичной пористости в породах и, как следствие, на их ФЕС. Если оценивать петрографические разновидности с точки зрения качества коллектора, то их можно разделить на три группы пород, которые с высокой, средней и низкой вероятностью образуют коллекторы с наилучшими ФЕС. Эффузивные и интрузивные породы преимущественно кислого состава и карбонатные отложения относятся к петротипам пород, которые с высокой вероятностью образуют коллекторы с наилучшими ФЕС. В последних отложениях наиболее активно протекают вторичные минералогические процессы, формирование трещиноватости, перекристаллизации. Ко второй группе, со средней вероятностью, относятся терригенно-карбонатные и метаморфические породы, такие как различные глинисто-кремнистые разности, метапесчаники. С низкой вероятностью могут образовываться коллекторы с благоприятными ФЕС в плотных глинистых разностях и магматических породах основного состава.

Применив полученное разделение пород по потенциалу качества ФЕС, с учетом плотности разрывной тектоники, на схеме выделены области, характеризующие качество ФЕС коллектора (рис. 4, A).

Распределение плотности аккумуляции тогурской нефти и районирование палеозойского резервуара

Определение перспективных районов в отношении нефтегазоносности для палеозойского резервуара основывается на учете комплекса тех же параметров, что и для резервуара коры выветривания, а именно учете плотности дизъюнктивных на- 
рушений, «предрасположенности» различных петротипов пород к образованию коллекторов (рис. 4 , А) и плотности генерации тогурских нефтей (рис. 1, Б). Вследствие чего районированы и проранжированы по степени перспективности зоны и участки с высоким потенциалом в отношении нефтегазоносности. Выделены три перспективные 30ны и участки в них. Ранжирование по перспективности участков обуславливается теми же критериями: плотностью тектонических разломов в пределах участка с учетом величины его площади (рис. 4, Б).

Зона 1 представлена шестью участками. Участок 1.1 расположен в восточной части Черемшанской мезоседловины, зоне ее сочленения с северным бортом Колтогорского мезопрогиба и западным склоном Средневасюганского мегавала. Границы данного участка подтверждаются отсутствием притоков УВ из фундамента в скважинах Пионерская 1, Южно-Пионерских 261, 263, Грушевых 211, 217 (рис. 4, Б, Пн1, ЮП261, ЮП263, Гр211, Гр217 - соответственно).

Участок 1.2 приурочен к западному склону Александровского свода. На территории данного участка пробурена скважина Новонадеждинская 1 (HН1), где из палеозойских отложений в интервале 2742-2792 м притока не получено. Перспективность участка 1.3, расположенного в зоне сочленения восточного борта Колтогорского мезопрогиба и западного склона Средневасюганского мегавала, подтверждается наличием газа в притоке из палеозойского резервуара в скважине Северо-Сутыгинская 2 (С-Сут2). Зона сочленения южного склона Ледового куполовидого поднятия, северо-восточного склона Каймысовского свода и юго-западного борта Колтогорского мезопрогиба соответствует расположению участка 1.4. На территории данного участка пробурена скважина Южно-Юганская 17(Ю-Юг17), вскрывшая переслаивание базальтов, диабазов, туфопесчаников, туфоалевролитов с прослоями карбонатных пород. При испытании притока в данной скважине не получено. Участки 1.5 u 1.6 приурочены к западному и восточному склонам Кедрово-Матюшкинского куполовидного поднятия соответственно. Пробуренная на территории участка 1.6 и вскрывшая отложения известняков скважина Приколтогорская 2 (ПК2, рис. 4, Б) при испытании положительного результата не дала.

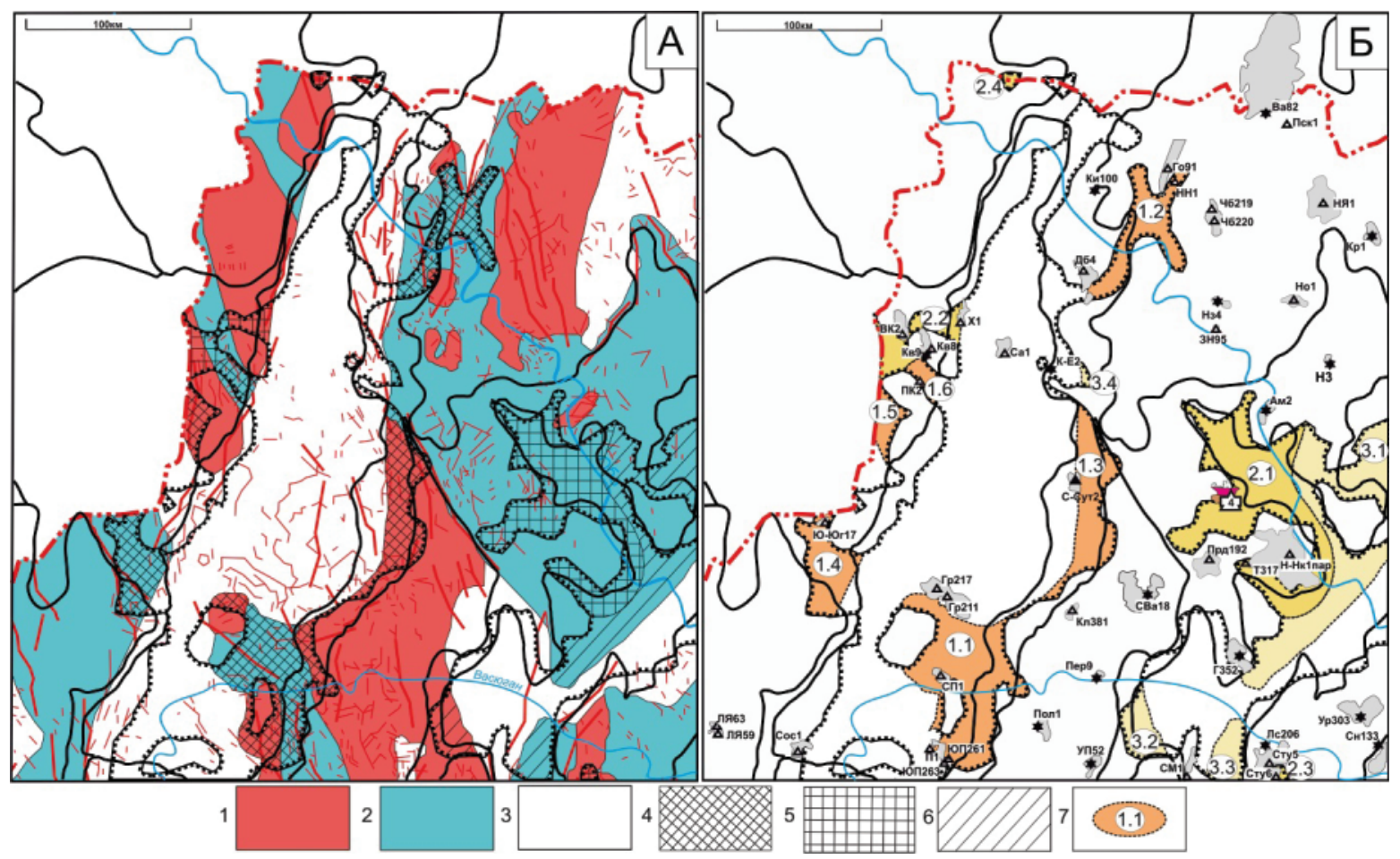

Рис.4. Колтогорский мезопрогиб и структуры обрамления. Внутренний палеозой. Специализированные области петротипов пород, тектонические нарушения и качество коллекторов (A), районирование и ранжирование участков по степени перспективности (Б). К схеме А: (1-3) - область петротипа: 1 - с вероятностью образования улучшенных коллекторов, 2 - с вероятностью образования хороших коллекторов, 3 - не образующая коллекторы; (4-6) зона коллектора: 4- с улучшенными ФЕС, 5- с хорошими ФЕС, 6 - с плохими ФЕС. К схеме (Б): 7 - перспективная зона (участок), указан номер ранжирования (интенсивность закраски пропорииональна степени перспективности). Остальные те же, что на рис. 1

Fig. 4. Koltogor mezodepression and its framing structures. The internal Paleozoic. Specialized areas of petrotypes, tectonic faults and reservoir quality (A), zoning and ranking of the high priority $(B)$. To figure $(A)$ : (1 -3) - area of petrotypes: 1 - probability of formation of improved reservoirs; 2 - probability of formation of a good collectors, 3 - not forming collectors; $(4-6)$ - area of reservoirs: 4 - with improved FCP; 5 - with good FCP; 6 - with bad FCP. To figure (B): 7 - potential zone (section), ranking number specified (intensity of area coloring is proportional to the degree of the area potential). The rest symbols are the same as in Fig. 1 
Зона 2 дифференцируется на четыре участка. Участок 2.1 приурочен к Северо-Чкаловскому врезу и зоне его сочленения с Мурасовским выступом и Трассовым куполовидным поднятием. Подтверждает свой высокий потенциал в отношении нефтегазоносности рассматриваемый участок наличием залежей УВ в палеозойских отложениях на Чкаловском месторождении. Северная часть Кедрово-Матюшкинского куполовидного поднятия относится к перспективному участку 2.2. Его пределы доказываются отсутствием притока в скважинах, расположенных вблизи границ участка. Участок 2.3 расположен в северной части Двойного выступа. Перспективность участка остается под вопросом в связи с отсутствием притока в скважинах Ступенчатые 5 и 6 (Сту5, Сту6). Небольшой участок 2.4 расположен в районе восточного склона Советско-Соснинского куполовидного поднятия. Сведений о прямых признаках нефтенасыщения на этом участке к настоящему времени не имеется.

Следующей по ранжированию идет зона 3 , разбитая на четыре участка. Выделение данных земель в отдельную зону обусловлено достаточно изменчивым значением плотности генерации тогурской нефти, а также неразвитой дизъюнктивной тектоникой. Участки 3.1 и 3.2 расположены в западной части Неготского мезопрогиба и на землях его сочленения с южным склоном Мурасовского выступа, соответственно. Участок 3.3 расположен в северной части Центрального прогиба. Локальный участок 3.4 приурочен к сочленению западного склона Александровского свода и восточного борта Колтогорского мезопрогиба. Прямых признаков, подтверждающих или опровергающих нефтеперспективность зоны 3 , на данный момент нет.

Проводя сопоставление прямых признаков нефтенасыщения глубоких скважин и закартированных перспективных зон и участков резервуара палеозойского фундалента, можно сделать вывод о связанности данных факторов, согласованность составляет около $70 \%$.

Резюмируя проделанную работу по районированию территории для освоения резервуара палеозойского фундалента, можно выделить следующие перспективные участки: 1) земли восточной части Черемшанской мезоседловины, земли сочленения мезоседловины с западным склоном Средневасюганского мегавала и с северным бортом Колтогорского мезопрогиба; 2) земли Северо-Чкаловского вреза и земли сочленения вреза с Мурасовским выступом и с Трассовым куполовидным поднятием, на которые сделан менее оптимистичный прогноз.

\section{Заключение}

Исследование проведено в рамках концепции преимущественно вертикальной миграции углеводородов. Предварительно выполнено восстановле- ние термической истории нефтематеринской тогурской свиты, с привлечением ранее полученных геотермических данных $[23,24]$. Кумулятивно учтены температуры локализованных палеоочагов генерации нефти, что позволило закартировать распределение плотности генерации нефтей [6]. Последующим интегральным анализом, с учетом фильтрационно-емкостных характеристик резервуаров и разрывной тектоники палеозоя, выполнено зональное нефтегеологическое районирование доюрского комплекса и ранжирование земель по степени перспективности.

Наиболее высокопотенциальным в отношении нефтегазоносности резервуара коры выветривания, а соответственно и приоритетным районом для поисков, является зона 1, охватывающая восточную часть Черемшанской мезоседловины и ее сочленение с северным бортом Колтогорского мезопрогиба и западным склоном Средневасюганского мегавала (порядка $3500 \mathrm{~km}^{2}$ ).

Наиболее оптимистичный прогноз для изучения и освоения резервуара коренного палеозоя выдвигается для тех же земель (зона 1), что и по коре выветривания, а уже менее оптимистичный - для Северо-Чкаловского вреза и зоны его сочленения с Мурасовским выступом и Трассовым куполовидным поднятием - зона 2 (порядка $5700 \mathrm{\kappa м}^{2}$ ).

Согласованность прогнозируемых перспективных участков доюрского НГК Колтогорского мезопрогиба и установленных прямых признаков нефтенасыщения составляет порядка $70 \%$.

Важно отметить следующий факт. На юго-востоке территория настоящего исследования включает выделенный перспективный район СевероЧкаловского вреза ... (участок 2.1 по коре выветривания, участок 2.1 по внутреннему палеозою), который ранее [2] также прогнозировался как перспективный (участок 2.0 по коре, участок 4.0 по палеозою). На юге территория настоящих исследований включает выделенный перспективный район восточной части Черемшанской мезоседловины ... (участок 1.0 по коре, участок 1.1 по палеозою), который ранее [2] также прогнозировался как перспективный (участок 2.8 по коре, участок 1.5 по палеозою). Таким образом, сопоставление на «стыковочных» землях показывает, что перспективность районов, выделенных настоящими детализированными исследованиями, в значительной степени согласуется с прогнозом, выполненным нами ранее [2].

Следует заметить, что выделенные перспективные зоны и участки для поисков не относятся к привычным положительным формам рельефа. Это говорит о необходимости корректировки отношения к поиску нефти, а именно не исключать целенаправленный поиск нефти в прогибах, в отрицательных формах подземного рельефа, на склонах поднятий. 


\section{СПИСОК ЛИТЕРАТУРЫ}

1. Развитие нефтегазового комплекса Югры, трудноизвлекаемыз запасы / С.Г. Кузьменков, В.И. Исаев, В.И. Булатов, Р.Ш. Аюпов, Н.О. Игенбаева, Ю.А. Кузьмин, П.А. Стулов // Известия Томского политехнического университета. Инжиниринг георесурсов. - 2018. - Т. 329. - № 11. - С. 103-113.

2. Нефтегазоносность коллекторов коры выветривания и палеозоя юго-востока Западной Сибири (прогнозирование трудноизвлекаемых запасов) / Г.А. Лобова, В.И. Исаев, С.Г. Кузьменков, Т.Е. Лунёва, Е.Н. Осипова // Геофизический журнал. 2018. - T. 40, - № 4. - С. 73-106.

3. Геологическое изучение и нефтегазоносность палеозойских отложений Западной Сибири / А.В. Ступакова, А.В. Соколов, Е.В. Соболева, Т.А. Кирюхина, И.А. Курасов, Е.В. Бордюг // Георесурсы. - 2015. - Т. 61. - № 2. - С. 63-76.

4. Luneva T., Lobova G., Fomin A. Oil and gas perspectives of weathering crust reservoir of Nurol'ka mega-basin according to data of Geothermics // IOP Conference Series: Earth and Environmental Science. - 2016. - V. 43. URL: http://iopscience.iop.org/ 1755-1315/43/1/012014/ (дата обращения 22.06.2019).

5. Сунгурова 0.Г., Мазуров А.К., Исаев В.И. Ресурсоэффективная стратегия поисков залежей нефти в доюрском основании Западной Сибири // Известия Томского политехнического университета. - 2014. - Т. 325. - № 1. - С. 147-154.

6. Лунёва Т.Е. Геотермический режим и реализация генерационного потенциала нефтематеринской тогурской свиты (северозапад Томской области) // Нефтегазовая геология. Теория и практика. - 2019. - T. 14. - № 2. URL: https://doi.org/ 10.17353/2070-5379/11_2019 (дата обращения 22.06.2019).

7. Геология нефти и газа Западной Сибири / А.Э. Конторович, Н.И. Нестеров, Ф.К. Салманов, В.С. Сурков, А.А. Трофимук, Ю.Г. Эрвье. - М.: Недра, 1975. - 680 с.

8. Kontorovich V.A. Petroleum potential of reservoirs at the Paleozoic-Mesozoic boundary in West Siberia: seismogeological criteria (example of the Chuzik-Chizhapka regional oil-gas accumulation) // Russian Geology and Geophysics. - 2007. - V. 48. № 5. - P. 422-428.

9. Catagenesis of organic matter at the top and base of the Jurassic complex in the West Siberian megabasin / A.E. Kontorovich, A.N. Fomin, V.0. Krasavchikov, A.V. Istomin // Russian Geology and Geophysics. - 2009. - V. 50. - № 11. - P. 917-929.

10. The role of Meso-Cenozoic tectonics in the formation of hydrocarbon pools in the southern parts of the Kaimysovy arch and Nyurol'ka megadepression / V.A. Kontorovich, M.V. Solov'ev, L.M. Kalinina, A.Y. Kalinin // Russian Geology and Geophisics. - 2011. - V. 52. - № 8. - P. 845-858.

11. Paleozoic-sourced petroleum systems of the West Siberian Basin. What is the evidence? / E. Ablya, D. Nadezhkin, E. Bordyg, T. Korneva, E. Kodlaeva, R. Mukhutdinov, M.A. Sugden, P.F. Van Bergen // Organic Geochemistry. - 2008. - V. 39. № 8. - P. 1176-1184.

12. Гатиятуллин Н.С., Баранов В.В. Возможность прогнозирования глубинной нефтегазоносности // Георесурсы. - 2015. № 4 (63). - С. 4-8.

13. Геологическое строение и оценка нефтегазоносности Западной половины Новосибирской области / 3.Т. Алескерова, М.С. Гу- ревич, С.В. Егоров, И.В. Литвиненко, Н.Е. Маковская, Т.И. ОсЫко. - Л.: ВСЕГЕИ, 1960. - 270 с.

14. Aryl isoprenoids in crude oils of the Nyurol'ka depression (southeast of Western Siberia) D.Yu. Chirkova, N.A. Krasnoyarova, 0.V. Serebrennikova, Ya.V. Olenev // Petroleum Chemistry. - 2017. - V. 57. - № 1. - P. 54-59.

15. Saltymakova D., Krasnoyarova N., Serebrennikova 0. Distinct features of crude oils from Nyurol'ka Depression (Southeast of Western Siberia) // Journal of Petroleum Science and Engineering. - 2017. - V. 154. - P. 91-99.

16. Распределение ароматических углеводородов в разрезе отложений нефтегазоносных комплексов (на примере месторождений Красноленинского свода) / Ю.В. Коржов, В.И. Исаев, А.А. Жильцова, 0.В. Латыпова // Геофизический журнал. 2013. - T. 35. - № 1. - C. 113-129.

17. Isaev V.I. Interpretation of High-Accuracy Gravity Exploration Data by Mathematic Programming // Russian Journal of Pacific Geology. - 2013. - V. 7. - № 2. - P. 92-106.

18. Нефтегазоносность нижнемеловых резервуаров Нюрольской мегавпадины / Е.Н. Осипова, Г.А. Лобова, В.И. Исаев, В.И. Старостенко // Известия Томского политехнического университета. - 2015. - Т. 326. - № 1. - С. 14-33.

19. Iskorkina A., Isaev V., Terre D. Assessment of Mesozoic-Kainozoic climate impact on oil-source rock potential (West Siberia) // IOP Conf. Series: Earth and Environmental Science 27. - 2015.P. 1-6. URL: http://iopscience.iop.org/article/10.1088/ 1755-1315/27/1/012023/pdf/ (дата обращения 22.06.2019).

20. Ковешников А.Е., Недоливко Н.М. Коры выветривания доюрских отложений Западно-Сибирской синеклизы // Известия Томского политехнического университета. - 2012. - Т. 320. № 1. - С. 77-81.

21. Кузина М.Я., Коржов Ю.В., Исаев В.И. Геохимическое и литологическое обоснование концепции «главного источника» доюрских залежей нефти Красноленинского свода // Известия Томского политехнического университета. - 2014. - Т. 324. № 1. - C. 32-38.

22. Koveshnikov A.E., Nesterova A.C., Dolgaya T.F. Fracture system influence on the reservoirs rock formation of OrdovicianDevonian carbonates in West Siberia tectonic depression // IOP Conference Series: Earth and Environmental Science. - 2016. V. 43. URL: http://iopscience.iop.org/article/10.1088/ 1755-1315/43/1/012008/pdf/ (дата обращения 22.06.2019).

23. Стоцкий В.В. Оценка геотемпературных условий генерации баженовских нефтей (Колтогорский мезопрогиб и структуры его обрамления) // Известия Томского политехнического университета. Инжиниринг георесурсов. - 2016. - Т. 327. - № 9. C. $18-28$.

24. Stotskiy V.V., Isaev V.I., Fomin M.A. An assessment of the geotemperature conditions of Bazhenov oil generation (Koltogor mezodepression and its framing structures) // IOP Conf. Series: Earth and Environmental Science 43. - 2016. URL: http://iopscience.iop.org/article/10.1088/1755-1315/43/1/012017 дата обращения 22.06.2019).

Поступила 25.06.2019 ح.

\section{Информация об авторах}

Лобова Г.A., доктор геолого-минералогических наук, доцент Отделения геологии Инженерной школы природных ресурсов Национального исследовательского Томского политехнического университета.

Лунёв $\boldsymbol{T}$ T.E., аспирант Отделения геологии Инженерной школы природных ресурсов Национального исследовательского Томского политехнического университета.

Исаева O.C., руководитель Томского филиала ФБУ «Территориальный фонд геологической информации по Сибирскому федеральному округу». 
UDC 553.98.068:551.73(571.16)

\title{
OIL AND GAS CONTENT OF WEATHERING CRUST AND PALEOZOIC IN KOLTOGOR MEZODEPRESSION (NORTH-WEST OF THE TOMSK REGION)
}

\author{
Galina A. Lobova', \\ lobovaga@tpu.ru \\ Tatyana E. Luneva', \\ tatyana.luneva93@gmail.com \\ Olga S. Isaeva ${ }^{2}$, \\ isaeva_sah@mail.ru \\ 1 National Research Tomsk Polytechnic University, \\ 30, Lenin Avenue, Tomsk, 634050, Russia. \\ 2 Territorial geological fund across Siberian Federal District, \\ 9, Mokrushin street, Tomsk, 634050, Russia.
}

The relevance of the research consists in the necessity of reproduction of raw materials base with hard-to-recover reserves in the PreJurassic oil and gas complex due to the depletion of the "classic» oil and gas horizons of Western Siberia.

The aim of this paper is to identify perspective areas for geological exploration in the Pre-Jurassic oil and gas complex in the Koltogor mezodepression - on the lands of the developed oilfield infrastructure of the Tomsk region.

The object of the study is the Pre-Jurassic reservoirs of the Permo-Triassic weathering crust and Paleozoic basement, within boundaries of the oil source Togur suite. The deposits in the weathering crust are associated with reservoirs formed over clay-siliceous, carbonate rocks, volcanic rocks of acid composition. In the inner Paleozoic, reservoirs correlate with secondary reservoirs formed to limestone and granite.

Method. The study is conducted within the framework of the concept of primarily vertical migration of hydrocarbons. The previous restoration of thermal history of the Togur suite, cumulatively taking into account the temperatures of the localized paleocenters of oil generation, made it possible to map the distribution of oil generation density. The subsequent integral analysis, taking into account the reservoir characteristics of reservoirs and the fault tectonics Paleozoic, is used to carry out zonal oil geological zoning of the pre-Jurassic complex and land ranking by degree of prospects.

Results. The oil geological zoning of the territory with high oil and gas potential has been carried out for the reservoirs of the Weathering Crust and the basement Paleozoic reservoirs separately. The priority area in the weathering crust is the eastern part of the Cheremshan mezosaddle, its adjacent area with the northern bead of the Koltogor mezodepression and the western hillside of the Srednevasyugan megawell (about 3,500 $\mathrm{km}^{2}$ ). The second section, with the same level of prospects, combines the North-Chkalovsky shut-in and its adjacent area with Murasov anticlinal nose and the Trass arched dome (about 5,700 $\mathrm{km}^{2}$ ). The identified oil and gas potential in the Pre-Jurassic reservoirs well confirms the conducted zoning and the accepted migration concept of hydrocarbons feeding reservoirs. The reliability of the forecast of promising lands of the Pre-Jurassic oil and gas complex is determined by comparison with the results of testing deep wells and is about $70 \%$.

\section{Key words:}

Togur suite, thermal history and density of oil generation, reservoirs of the Weathering Crust and Paleozoic basement, oil geological zoning, Koltogor mezodepression.

\section{REFERENCES}

1. Kuzmenkov S.G., Isaev V.I., Bulatov V.I., Ayupov R.Sh., Eginbaeva N.0., Kuzmin Yu.A., Stulov P.A. Development of Yugra oil and gas complex, hard-to-extract reserves. Bulletin of the Tomsk Polytechnic University. Geo Assets Engineering, 2018, vol. 329 , no. 11, pp. 103-113. In Rus.

2. Lobova G.A., Isaev V.I., Kuzmenkov S.G., Luneva T.E., Osipova E.N. Oil and gas content reservoirs of the weathering crust and Paleozoic of the southeast of Western Siberia (forecasting hard-to-recover reserves). Geophysical Journal, 2018, vol. 40, no. 4, pp. 73-106. In Rus.

3. Stupakova A.V., Sokolov A.V., Soboleva E.V., Kiryukhina T.A., Kurasov I.A., Bordyug E.V. Geological survey and petroleum potential of Paleozoic deposits in the Western Siberia. Georesources, 2015, no. 2 (61), pp. 63-76. In Rus.

4. Luneva T., Lobova G., Fomin A. Oil and gas perspectives of weathering crust reservoir of Nurol'ka mega-basin according to data of Geothermics. IOP Conference Series: Earth and Environmental Science, 2016, vol. 43. Available at: http://iopscien- ce.iop.org/1755-1315/43/1/012014/ (accessed 22 June 2019).

5. Sungurova 0.G., Mazurov A.K., Isaev V.I. Resource efficient search strategies of oil deposits in the pre-Jurassic base of Western Siberia. Bulletin of the Tomsk Polytechnic University, 2014, vol. 325 , no. 1, pp. 147-154. In Rus.

6. Luneva T.E. Geothermal regime and realization of the generation potential of the oil source Togur suite (north-west of the Tomsk region). Oil and Gas Geology. Theory and practice, 2019, vol. 14, no. 2. In Rus. Available at: http://www.ngtp.ru/rub/2019/ 11_2019.html/ (accessed 22 June 2019).

7. Kontorovich A.E., Nesterov N.N., Salmanov F.K., Surkov V.S., Trofimuk A.A., Erve Yu.G. Geologiya nefti i gaza Zapadnoy Sibi$r i$ [Oil and gas geology in Western Siberia]. Moscow, Nedra Publ., $1975.680 \mathrm{p}$.

8. Kontorovich V.A. Petroleum potential of reservoirs at the Paleozoic-Mesozoic boundary in West Siberia: seismogeological criteria (example of the Chuzik-Chizhapka regional oil-gas accumulation). Russian Geology and Geophysics, 2007, vol. 48, no. 5, pp. $422-428$. 
9. Kontorovich A.E., Fomin A.N., Krasavchikov V.0., Istomin A.V. Catagenesis of organic matter at the top and base of the Jurassic complex in the West Siberian megabasin. Russian Geology and Geophysics, 2009, vol. 50, no. 11, pp. 917-929.

10. Kontorovich V.A., Solov'ev M.V., Kalinina L.M., Kalinin A.Y. The role of Meso-Cenozoic tectonics in the formation of hydrocarbon pools in the southern parts of the Kaimysovy arch and Nyurol'ka megadepression. Russian Geology and Geophisics, 2011, vol. 52, no. 8, pp. 845-858.

11. Ablya E., Nadezhkin D., Bordyg E., Korneva T., Kodlaeva E., Mukhutdinov R., Sugden M.A., Van Bergen P.F. Paleozoic-sourced petroleum systems of the West Siberian Basin. What is the evidence? Organic Geochemistry, 2008, vol. 39, no. 8, pp. 1176-1184.

12. Gatiyatullin N.S., Baranov V.V. Ability to predict the deep oil and gas. Georesources, 2015, vol. 63, no. 4, pp. 4-8. In Rus.

13. Aleskerova Z.T., Gurevich M.S., Egorov S.V., Litvinenko I.V., Makovskaya N.E., Osyko T.I. Geologicheskoe stroyenie i otsenka neftegazonosnosti Zapadnoy poloviny Novosibirskoy oblasti [Geological structure and petroleum potential assessment of the Western part of the Novosibirsk Region]. Leningrad, VSEGEI Publ., 1960. $270 \mathrm{p}$.

14. Chirkova D.Yu., Krasnoyarova N.A., Serebrennikova O.V., Olenev Ya.V. Aryl isoprenoids in crude oils of the Nyurol'ka depression (southeast of Western Siberia). Petroleum Chemistry, 2017, vol. 57, no. 1, pp. 54-59.

15. Saltymakova D., Krasnoyarova N., Serebrennikova 0. Distinct features of crude oils from Nyurol'ka Depression (Southeast of Western Siberia). Journal of Petroleum Science and Engineering, 2017, vol. 154, pp. 91-99.

16. Korzhov Yu.V., Isaev V.I., Zhiltsova A.A., Latypova 0.V. Distribution of aromatic hydrocarbons in the section of deposits of oil and gas complexes (on the example of Krasnoleninsky arch deposits). Geophysical journal, 2013, vol. 35, no. 1, pp. 113-129. In Rus.

17. Isaev V.I. Interpretation of High-Accuracy Gravity Exploration Data by Mathematic Programming. Russian Journal of Pacific Geology, 2013, vol. 7, no. 2, pp. 92-106.
18. Osipova E.N, Lobova G.A., Isaev V.I., Starostenko V.I. Oil-gas potential of the Lower Cretaceous reservoirs in the Nyurol'ka megadepression. Bulletin of the Tomsk Polytechnic University, 2015, vol. 326, no. 1, pp. 14-33. In Rus.

19. Iskorkina A., Isaev V., Terre D. Assessment of Mesozoic-Kainozoic climate impact on oil-source rock potential (West Siberia). IOP Conf. Series: Earth and Environmental Science, 2015, no. 27, pp. 1-6. Available at: http://iopscience.iop.org/article/10.1088/1755-1315/27/1/012023/pdf/ (accessed 22 June 2019).

20. Koveshnikov A.E., Nedolivko N.M. The weathering crusts of the pre-Jurassic deposits of Western-Siberian geosyneclise. Bulletin of the Tomsk Polytechnic University, 2012, vol. 320, no. 1, pp. 77-81. In Rus.

21. Kuzina M.Ya., Korzhov Yu.V., Isaev V.I. Geochemical and lithological justification of «the main source» concept of pre-Jurassic oil deposits in Krasnoleninsk Arch (Tyumen Region). Bulletin of the Tomsk Polytechnic University, 2014, vol. 324, no. 1, pp. 32-38. In Rus.

22. Koveshnikov A.E., Nesterova A.C., Dolgaya T.F. Fracture system influence on the reservoirs rock formation of OrdovicianDevonian carbonates in West Siberia tectonic depression. IOP Conference Series: Earth and Environmental Science, 2016, vol. 43. Available at: http://iopscience.iop.org/article/10.1088/ 1755-1315/43/1/012008/pdf/ (accessed 22 June 2019).

23. Stotskiy V.V. Assessment of geotemperature conditions of bazhenov oil generation (Koltogor mezodepression and its framing structures). Bulletin of the Tomsk Polytechnic University. Geo Assets Engineering, 2016, vol. 327, no. 9, pp. 18-28. In Rus.

24. Stotskiy V.V., Isaev V.I., Fomin M.A. An assessment of the geotemperature conditions of Bazhenov oil generation (Koltogor mezodepression and its framing structures). IOP Conf. Series: Earth and Environmental Science, 2016, no. 43. Available at: http://iopscience.iop.org/article/10.1088/1755-1315/43/1/ 012017 (accessed 22 June 2019).

Received: 25 June 2019.

\section{Information about the authors}

Galina A. Lobova, Dr. Sc., associate professor, National Research Tomsk Polytechnic University.

Tatjana E. Luneva, postgraduate, National Research Tomsk Polytechnic University.

Olga S. Isaeva, Head of Tomsk branch of federal state institution «Territorial geological fund across Siberian Federal District». 